\title{
Political Conception of Sufism Leader in Java
}

\author{
Zubair \\ Magister Program of Arabic Language and Literature \\ Syarif Hidayatullah State Islamic University Jakarta \\ Indonesia \\ zubair@uinjkt.ac.id
}

\begin{abstract}
This article relates the political conceptions and the responses of Sufism leader in Java. The purpose of this study is to discover views and practices of Sufism scholars in Java regarding Islamic law of engagement in politics. Sufism leaders who became the subjects of the data were representatives of three provinces. The data were obtained through intensive interviews, aside from utilizing literary document data. To analyze the existing data, the author used (istinbat) analysis of Islamic law. The result of analysis showed that Javanese views of Sufism leaders regarding Islamic law of engagement in politics were categorized into two natures of the law, namely: 1) Fardhu kifayah (obligatory), with reason that leadership must exist to organize Muslims' benefit; and 2) Mubah (allow), because the potency of benefit was likely bigger than the potency of deterioration. The differences of these views caused distinctions of response and behavior of Sufism scholars in practical politics in Indonesia. Those who saidFardhu Kifayah involved themselves in stewardship of political parties; while some who said Mubah involved themselves while some others did not.
\end{abstract}

Keywords-Sufism, Thariqa, Politics, Islam, Java.

\section{INTRODUCTION}

In the early 1970s, when Indonesia started to reveal modern life, Sufism appeared and revived as a religion organization that gave solution to face materialism tendency and tensity of dominant foreign cultures' influence[1]. There are two explanations for Sufism. First, Sufism is defined as a strict obedience to Islamic sharia rules that must be practiced properly, either ritually or socially, such as by doing wira ' $\bar{l}$ and practicing riyā $\underline{d} a h$. Second, Sufism is explained as a whole ritual system for spiritual training [2].

Sufism can also be defined as a way into the God under preceptor's guidance [3]. For that reason, in Sufism, there is also a genealogy concept development, which is a chain that strengthens preceptor's authority. Through that term, transmission lines of authority and blessing are created. By this method, preceptor's spiritual power can be transmitted to the next generation. Sufism, in the tradition of Indonesian society can be divided into two forms, first, Sufism that is practiced based on procedures done by Sufism organizations. Second, Sufism that is practiced in manners outside the Sufism organizations congregations [4].

In 90s, Martin van Bruinessen (1992) saw that Sufism in
Indonesia was growing rapidly, either in urban or rural areas. According to him, one of the causing factors was social changing that happened, in which the modernization process accompanied by the fading of traditional social ties, had evoked social and emotional emptiness. Sufism and other materialisms could fulfill the needs felt by those people. That informal organization offered social and emotional atmospheresthat were hard to get in daily life. Besides, depoliticization process of Islam in several decades encouraged people not to give attention anymore to Islamic politic goals but to the spiritual experience and individual moral. This development also rose Sufism popularity.

In reality,Indonesia social politicshas characteristics that are so honor to the Islamic teacher including Sufism leader, who is a figure of a teacher/murshid teaching the values of people spiritual. On the other side, Islam and politic are considered as two contradictory entities, where Islam is assumed as a sacred thought and has no relation to democratic politics. This brings about the thought that the Islamic circles, especially their' elites,are enough to handle things that relate to their people pray and to anything that can make them close to their God. yet, the politics handlesthe people that understand about government, for there are tendency of corruption, collusion and nepotism, so Islamic teacher is not appropriate to enter and to get involved in politics.

The result of Baihaqi's research (2011) showed illustration that Islamic elites who were Islamic teachers evidently did not guide their people only in religion aspect (rituality), but also in political aspect. Horikishi (1987) also hadsimilar viewpoint that Islamic teacher had a role as a catalyzer (a side that can influence a change to improvement) of social change. In this context, Horikishi showed that Islamic teachers played their role creatively in social change [5]. It was not because the Islamic teachers tried to prevent the effect of social change that happened, but they pioneered social change by using their terms instead.

That condition colored phenomenon of Sufism world that is identified as more emphasizing to the afterlife centric, apparently in the real world, the leaders of Sufism and their people also contributed in the success of the political elite and became a very competitive power for other candidates. Mark R. Woodward (2008), an ethnologist from the United States who conducted Javanese Islamic research, said that Javanese Islam 
was unique, not because it preserved aspects of pre-Islamic culture and religion, but because of Sufi concepts of cultivation, mystical path, and perfection of human were applied in a cult of the kraton (imperial cult). Thus, State religion is a model of traditional Javanese conception of social rules, rituals, and other aspects of sociallife.

Development transmission of renewal ideas in Indonesia, according to Azra [6], was through a network of scholars involving very complex processes. This network produced works of their scientific processes, especially the field of Hadith and Sufism. Their work would reveal much about how the idea of Islamic renewal was transmitted from a center network to different parts of the Muslim World.

According to Martin van Bruinessen, the most influential Sufism in East Java among Javanese ethnic is the Qadiriah wa Naqsyabandiyah congregation centered at Darul Ulum Islamic Boarding School, Rejoso, Jombang. In 1975, Islamic teacher, Musta'in Romly from Darul Ulum Islamic Boarding School, Rejoso, the most charismatic and the most ambitious Sufism sheikh, was chosen as a leader of Jam'iyah Ahl al-Thariqah alMu'tabarah ([7, p. 171]). In the lead up to the 1977 general election, Islamic teacher, Musta'in Romly publicly supported the Golongan Karya which was the government's political organization at the time. His decision was received criticism from some Sufism figures and agreed to remove him from his position as the leader of Jam'iyyah. Since Musta'in Romly did not want to retire from his position, then Sufism leader formed a new organization,Jam'iyyah al- Thariqah al-Mutabarah alNahdhiyah,in Nahdatul Ulama Congress in Magelan 1979. Meanwhile, Kiai Musta'in Romly remained as the leader of the previous organization until his death in 1984 ([7, p. 172]).

Moreover, the mursyid of Qadiriyah wa Naqsyabandiah tribe in the al-Inabah Islamic Boarding School, Suryalaya, Tasikmalaya, K.H. Shafibul Wafa Tajul Arifin, popularly known as Abah Anom, supported the Golongan Karya (Golkar) Group in the 1971 election [8]().

The involvement of Sufism leaders in politics in Java had been widely prevalent. 'Abdul Karim, the mursyid of Qadiriyah wa Naqsyabandiyah Sufism in Banten, consolidated communication and coordination when the greatest peasant rebellion occurred in Banten in 1888. Although he lived in Mecca, Hajj Marjuki was one of his caliphs suspected by the Dutch as one of the instigators behind that rebellion [7, p. 92](van Bruinessen, 1992, 92; Tohir, 2002, 32-33). The rebellion by another 'Abdul Karim caliph was conducted by Islamic teacher, Kasan Tafsir, from Krapyak who was involved in the Sukoharjo Events. Other Sufism leaders who also carried out the rebellion in Lombok were Teacher Bangkol, a follower of Qadiriyah wa Naqsyabandiyah Sufism that received thought about Sufism from his brother Abdurrahman and his cousin Thayib who studied the Sufism in Mecca [7, p. 93].

Furthermore, there was Islamic teacher, Rifa'i Kalisalak as the murshid of the Rifa'iyah Sufism, who performed resistance to the Dutch colonialists in the nineteenth century that was arrested, prosecuted, exiled to Ambon and died around 1876, although his grave has not been found [8].

In the $17^{\text {th }}$ Century, a number of scholars Sufism were fighting against the Dutch colonials, such as Sheikh Yusuf alMaqassari (1627-1699). Sheikh Yusuf took the fight against the invaders in Banten with the Sultan of Banten, so that he was exiled to Srilanka and Cape Town. Wherever he was, Sheikh Yusuf [6, p. 271-287] always engaged in socio-political activities, including waging war with invaders.

Sharia and mysticism or especially shari'a and Sufism are always attractive to discuss. In relation to the background above, the focus of this study is to see how the Sufism leaders view politics in term of fiqh siyasah; and how is the form of political participation of Sufism leaders in the political stage and power?

What Sufism leader intended in this article is murshid who has right to receive people inauguration to become member of his Sufism organization. Because of the large number of Sufism leaders in Java and the extent of the areas to be studied, the researcher made the following lmitations (1) Sufism leaders affiliated with certain political parties, (2) anti-Sufism leaders in political parties, and (3) Sufism leaders who were neutral or not affiliated with a particular political party.

\section{METHOD}

The data of this paper were the result of research conducted in 2015 and representing Sufi's leader of 4 of 6 provinces in Java i.e. Banten, West Java, and Middle Java. There were seven Sufi's leaders as the subjects of research, i.e. 1) Tuangku Syekh Muhammad Ali Hanafiah (born in 1976), murshid and the founder of Tariqa Qadiriyah Hanafiyah in South Tangerang, Banten; 2) Abuya Muhtadi Dimyathi (born in 1953), murshid thariqa Syadziliyah in Pandeglang, Banten, 3) Suprapto Kadis (1929-2011), murshid and the founder of Tariqa Kadisiyah in Bandung, West Java; 4) KH. Maimun Zubair (born in 1928), murshid Tariqa Idrisiyah Syadziliyah in Sarang-Rembang, Middle Java; 5) KH. Muhammad Munif Zuhri (born in 1962), murshid Tariqa Naqsyabandiyah Khalidiyah in Giri Kusuma, Mranggen-Demak, Middle Java, 6) KH. Kankan Zulkarnaen (born in 1952), murshid Tariqa Qadiriyah wa Naqsyabandiyah in Suryalaya- Tasikmalaya, West Java; dan 7) Syekh Muhammad Fathurrahman (born in 1973), murshid Tariqa Idrisiyah in Pegendingan-Tasikmalaya, West Jawa. The samples were chosen by using proportional sampling based on their involvement or not in political practices. The primary sources of this paper were from interviews of the subjects, aside from utilizing literary document data. The approach used in this paper was Islamic jurisprudence or usul al-fiqh in political manner. This approach was to find the participants' arguments based on the Quran and Sunnah that led their political thoughts and actions. To support this approach, Author used sociology 
knowledge to analyze the relation of social live to the political conception of Sufi's leaders in Java.

\section{RESUlT AND DISCUSSION}

\section{A. The Basis of Political Law}

The basis of law referred here is the basis of law in Islam. Explicitly, the Sufism leaders did not mention about their basis and foothold in doing political interpretation, either in istimbāt $\bar{\imath}$ form or tatbīq $\bar{\imath}$ form ${ }^{1}$. The fundamental of law istimbāti used by them was understood from the way of giving argumentation in issuing opinion and taking political attitude. Basically, they were not out of the applicable source and postulate of law in Ahlussunnah wal Jamaah circle, both agreed and disputed. Postulates that were agreed are Al-Qur'an, sunnah, ijmāa, dan qiyās, while the disputed were istih̆sān, sadd zal żarī'ah,

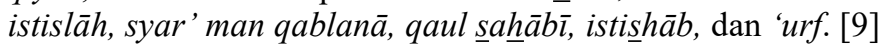

KH. Maimun Zubair, KH. Muhammad Munif Zuhri, and Abuya Muhtadi Dimyathi were practically involved in political party management. When they were asked they mentioned that every Muslim was obliged to do amar makruf and nahi munkar. The quoted verse is the commandment of God: "And from among you there should be a party who invite to good and enjoin what is right and forbid the wrong, and these it is that shall be successful" (Quran: 3/104)

Based on the verse above, there must be a person among the Muslim who positions himself as missionary to persuade into goodness and prevent from deterioration.

While engaging in politic, every action and behavior must imitate Rasulullah SAW, KH. Maimun Zubair [10] (4/10/2015) quoted commandment of God: "and whatever the Messenger gives you, accept it, and from whatever he forbids you, keep back, and be careful of (your duty to) Allah;" (Quran: 59/7). The quotation of this verse also showed that Sufism leaders became Sunnah of the Holy Prophet as the basis of his politicalinauguration.

The rules of fiqhiyah related to politics were also always applied by the Sufism leaders. The fiqh rules that serve as a pattern for determining various political policies are [10, p. 65]: lā yunkaru taghayyur al ahkām bi taghayyur al zamān (It was not denied the change of provisions by the change of time).

The change of governmental system after Reformation Era by Sufism leaders was considered as part of social interest and necessity. Therefore, they did not question the type and the form of the existing governance, as long as its aim was to keep the people's benefit. In the New Order Era, there were only three

\footnotetext{
1 Inauguration is divided into istimbātī and tatbīqui. Istimbātī is an attempt to exert every ability to discover the practical law based on postulates of law in detail, while tatbīq $\bar{\imath}$ is an attempt to apply the law which has been instituted in the form of practical action.
}

political parties existed, after no longer considered relevant, Indonesian Legislative Assembly changed the system into multiparty system. Some of Sufism leaders took part within this change of system. KH. Maimun Zubair (5/10/2015) himself had enjoyed the system of political system in the New Order Era and the following multiparty system in ReformationEra.

From earlier description, it is explained that the involvement of Sufism leaders in political parties was in order of the framework of $d a^{\prime}$ wah for the sake of achieving the benefit of humankind. This part was an implementation of the rule of law[11, p. 257]: al tasarruf 'alā al ra'̄yyyah manūt bi al maslahah (The policies of the government must be based on people's benefit). It means that no matter what the rules made or polices decided by government and legislatives are, they must refer to the benefits of people. This norm contains the meaning that every government's policy must consider people's aspiration. The reason of this norm is that the government's decision will not be effectively applied if people's aspiration is not taken into account. In this case, government may not create a legislation that is disadvantageous to people. Thus, governmental policies must be in accordance to public importance and not for itselfinterest.

Another norm that also seems to be applied by Sufism leaders in observing reality and behaving towards politics is that proper tradition as a part of law itself. [11, p. 27]: al 'âdah muhakkamah (the tradition of people can be a law).

For so long, Indonesia has possessed a proper tradition as local wisdom that is later affirmed as part of positive law that its application is effective nationally. Beside tradition, new habits are formed after getting touched with international world. For Sufism leaders, as long as those traditions donotcontradictIslamicfundamentalprinciple,thenthey are partsoflawthatmustobey.Pancasila, especially 1945 Constitution has experienced several amendments. Those amendments are a new tradition in our constitutionalsystem.

This norm shows that a law applied by government must be in accordance to the local tradition. This is for people who will carry out the law or governmental regulations will not have any objections because the law contradicts their traditions. However, traditions that can be used as fundamental law here must not contradict the Islamic Sharia's spirit for in the norm is said [11, p. 207]: dar 'al mafāsid awlā min jalb al masālih (avoiding evil is more priority than taking interests). Based on this norm, government must create political policies and legislations that agree with priority scale. If there are two cases that contradict each other; one is advantageous while it is dangerous on the other side, then the one that is prioritized is the principle that avoids danger. In this case, permission of gambling, prostitution and liquors may result in profitable foreign exchange but the danger that they cause in damaging young generation is much bigger.

The norms above are part of using ijtihad method based on istislah or maslahah mursalah, sadd zariah, and urf. 


\section{B. Purposes and Funtions of Political Intsitute}

Based on the previous description, Sufism leaders almost agreed to state that the purpose of political institutes, whether in trias-politica; executive, legislative, and judicative, or supportive institutes outside trias-politica, were to create benefits for humankind. The difference lied on their demeanor towards those political institutes. For those who joined the political institutes wish that political parties can be used as vehicles to achieve that glorious goals, while those who were not involved in assumed that the existing political institutes were not reliable to develop society, especially in spiritual aspect. This purpose has the same purpose with religious purpose, that is "And We have not sent you but as a mercy to the worlds" (Quran: 21/107)

This purpose is universal. Moreover, Tuangku Syekh Muhammad Ali Hanafiah [12] (28/11/2015) interpreted rahmah in this context as affection. That means people are obligated to spread affection to the entire universe including the matter of state regulator that must be based on affection to each other andnature.

As for function of political institutes according to Sufism leaders who joined political parties, was a vessel of $d a^{\prime}$ wah in a broader meaning. Sufism leaders outside the parties agreed that $d a ' w a h$ needed a vessel and organization, but not necessarily in the form of political parties. The reason was that the political parties were always accompanied by pragmatic goals that can change the good relationship of Muslim fraternity. Aside from that, political parties can also shrink themselves in order to be able to perform $d a^{\prime}$ wah to every group ofsociety.

\section{Position of Political System and Government of Indonesia}

As mentioned above, many leaders did not question the system and Indonesian governmental form. In fact, Syekh Muhammad Fathurrahman [13] (Yusuf, 14/10/2015) considered that Negara Kesaturan Republik Indonesia (NKRI) is an idea that is final. The same statement is also stated by Abuya Muhtadi Dimyathi [14] (21/10/2015) that an attempt to replace Pancasila and 1945 Constitution as state ideology and foundation is an act of treason.

For Sufism leaders, it was not the form nor the system that was important but how they can be used as ways to achieve goals. Surely, the government must exist because without it, the purpose of da'wah will be impossible to achieve. This matter is based on one of norms [15] :mā lā yatimmu al wājib illa bih $\mathrm{fa}$ huwa wäjib (If the obligatory cannot be done without something, that something is the obligatorytoo)

If democratic system that is followed by Indonesia requires the existence of political parties, then they must exist. These parties are the vessels to convey people's aspiration that will be processed into rules and legislations. Even though, Tuangku Syekh Muhammad Ali Hanafiah (28/11/2015) considered that democratic system was a product of Dajjal that was extremely harmful for Muslims. However, he did not deny that democracy as system has already been followed by the people of Indonesia.

\section{CONCLUSION}

The Islamic views of politic manner of Sufi's leader in Java, especially of the seven subjects of this research are commonly similar that basically possible or permitted, it is just different in their behaviour and actions. Their politic of views are based on Islamic laws that are ahl al-sunnah wa al-jama'ah. They make the both agreed Islamic sources, i.e. Quran, Sunnah, Ijma', and Qiyas and disagreed Islamic sourcesistishlah, sadd al-dzari'ah, and 'urf as the argument of views. The Javanese views of Sufism leaders regarding law of engagement in politics are categorized into two natures of the law, namely: 1) Fardhu kifayah (obligatory), with reason that leadership must exist to organize Muslims' benefit; and 2) Mubah (allow), because the potency of benefit is likely bigger that the potency of deterioration.

The differences of these views cause distinctions of demeanor and behavior of Sufism scholars in practical politics in Indonesia. Those who say Fardhu Kifayah involve themselves in stewardship of political parties asmember and official board of the parties namely KH. Maimun Zubair, KH. Muhammad Munif Zuhri, and Abu Muhtadi Dimyathi; and secondly who did not involve are Tuanku Syekh Muhammad Ali Hanafiah, Suprapto Kadis, KH. Kankan Zulkarnaen, and Syekh Muhammad Fathurrahman.

In one side, the arguments of those who involved agreed that political parties were as the institution of Islamic mission. They wanted to colour the parties' decision by Islamic values and broughtit to implement that values in the rules of the state,. and to advice spiritually the members of parties and government.

Even though, they acknowledged that this were a difficult thing to do, those phenomena and situations were perceived by Abuya Muhtadi Dimyathi in PKB (Party of National Awakening) which led him to establish Majelis Mudzakarah Muhtadi Cidahu Banten (M3CB), the Islamic dakwa institution. KH. Maimun Zubair, the member of Advisory Board of PPP (Party of Unity and Development) was perceiving those, as well as KH. Muhammad Munif Zuhri [16] . A part from those situations, they were still on the duty to promote virtue and prevention ofvice.

In the other side, those who saidMubah involved themselves, while some did not. Those who did not involve in politic practice argued that politic was a place for everybody how wanted to obtain power and influence.

For this propose, somebody was usually a pragmatic and permissive personality. Therefore, they prioritizes to build the institution of dakwa without political power and influence 
intention of the members of parties, and were freely to spread Islamic teaching for all.

Tuangku Syekh Muhammad Ali Hanafiah had built several Islamic institutions i.e. Pondok Pesantren Tasawuf Rabbani in Solok, TICI (Tasawuf Islamic Centre Indonesia) in Jakarta, DUTI (The Council of Ulama Thareqa of Indonesia) dan (The Council of Thariqa Ulama of ASEAN) etc. Suprapto Kadis had YPP (Paramartha Foundation for Education) atau YIP (Islamic Paramartha Foundation), PPIK (Unity of Islam ParamarthaKadisiyah in Bandung, SGAH (Sanggar Gusti Al-Hujurat Foundation) in Bandung, Kadisiyah Universal Group in Cilegon, and Tarekat Nur Islamiyah Group in Bekasi. Both KH. Kankan Zulkarnaen [17] and Syekh Muhammad Fathurrahman stayed on leading their Islamic Boarding Schools.

\section{REFERENCES}

[1] A. Syafi'I Mufid, Tangklukan, Abangan dan Tarekat : Kebangkitan Agama di Jawa. Jakarta: Obor, 2006

[2] A. Hanun dkk, Pesantren di Jawa : Asal-usul, Perkembangan dan Pelembagaan. Jakarta: Direktorat Jenderal Kelembagaan Agama Islam Departemen Agama, 2006. pp. 133-134

[3] S. Muhammad Amin al-Kurdi al Irbili, Tanwir al-Qulub fi Mu'amalat Allaam al-Qulub. Halb: Dar al-Qalam al-Arabiy, 1991. p. 467

[4] Z. Dhofier, Tradisi Pesantren: Studi tentang Pandangan Hidup Kyai. Jakarta: LP3ES, 1994.

[5] A. Wahid, Benarkah Kiai Menbawa Perubahan Sosial? Sebuah Pengantar. dalam Horikoshi, Kiai dan Perubahan Sosial. Jakarta: P3M, 1987.

[6] A. Azra, Jaringan Ulama Timur Tengah dan Kepulauan Nusantara abad XVII \& XVIII: AKar Pembaruan Islam di Indonesia, 3rd Edition. Jakarta: Kencana, 2007.

[7] M. Van Bruissen, Tarekat Naqsyabandiyah di Indonesia; Survei Historis, Geografis, dan Sosiologi. Jakarta: Penertbit Mizan, 1992.

[8] A.Djamil, Perlawanan Kiai Desa: Pemikiran GErakan Islam KH. Rifa’ $i$ Kalisalak. Yogyakarta: LkiS, 2001.

[9] M. Abu Zahrah, Us ūul al-Fiqh. Cairo: Dār al-Fikr al-Arabī, 1958. pp. 9092.

[10] KH. Maimun Zubair in Sarang, 4-5 ${ }^{\text {th }}$ October 2015.

[11] A. Ahmad Ali Nawawi, Al-Qawā'id Al Fiqhiyah. Damaskus, Dar AlQalam, 1994.

[12] Tuangku Syekh Muhammad Ali Hanafiah in Tangerang, 28 $8^{\text {th }}$ November2015

[13] Sandra Yusuf in Tasikmalaya, $14^{\text {st } O c t o b e r} 2015$

[14] Abuya Muhtadi Dimyathi in Banten, $21^{\text {st }}$ October2015

[15] S. al-Sanhājī Al Qarāfī, Anwār al-Burūq fì Anwā' al-Furū. Vol. I, Makkah: T.tp. 'Alam al-Kutub, 1948. p. 166.

[16] KH. Munif Muhammad Zuhri in Demak, $5^{\text {th }}$ October2015

[17] KH. Kankan Zulkarnaen in Suryalaya, $14^{\text {th }}$ October2015 